\title{
The Impact of Infrastructure on Foreign Direct Investment:
}

\section{The Case of Pakistan}

\author{
Dr. Ch. Abdul Rehman \\ Rector, Superior University, Lahore, Pakistan \\ Muhammad Ilyas \\ Lecturer, Department of Economics, Superior University \\ Lahore, Pakistan \\ Hassan Mobeen Alam (Assistant Professor) \\ $\&$ \\ Muhammad Akram (Corresponding author) \\ Hailey College of Commerce, University of the Punjab \\ Quaid-e-Azam Campus, Lahore, Pakistan \\ E-mail: makram@hcc.pu.edu.pk
}

Received: November 3, $2010 \quad$ Accepted: December 7, $2010 \quad$ doi:10.5539/ijbm.v6n5p268

\begin{abstract}
Purpose - The purpose of this study is to analyze the role of infrastructure for and in ascertaining captivations of foreign direct investment (FDI). This work aims to investigate the effects of host country's infrastructure availability along with exchange rate and market size on inflows of FDI towards Pakistan.

Design/methodology/approach - This study employs autoregressive distributed lag (ARDL) approach to cointegration and an error correction model based on ARDL approach using time series data for the period 1975-2008 in case of Pakistan.

Findings - This paper reveals a strong positive impact of infrastructure in attracting foreign direct investment, in short and in long run, in case of Pakistan.

Practical implications - The findings can be used to help out government policy makers on FDI as well as are equally important for international financial lender/donor agencies and countries interested in rehabilitation activities of flood-affected areas with special reference to infrastructure and FDI while extending financing facilities to Pakistan.

Originality/value - This study contributes in the following manner: first, it gives better impending and understanding for decision making about foreign direct investment in Pakistan. Second, it is the first effort that an exclusive study on FDI with special reference to infrastructure made in Pakistan. Third, it depicts the closer relationship between FDI attractiveness and infrastructure availability.
\end{abstract}

Keywords: Infrastructure, Exchange rate, FDI, ARDL, Pakistan

\section{Introduction}

The pivotal contribution of FDI in the economic progress has been well recognized in the literature. The outcomes of foreign direct investment are far important for developing countries as to developed countries as developing nations are mostly short of capital, lack of access to modern technology etc. FDI resolves these lacking along with providing benefits to foreign investor. The literature on FDI explores various determinants having the mutual benefit of investor as well as host nation.

The process of liberalization in international trade in Pakistan was originated during early 1980. The market based economic reforms and policies gradually open the doors for foreign investor in Pakistan. The government provided various trade facilitation incentives like tax concessions, tariff reduction, credit facilities and also 
softened foreign exchange controls (Khan, 1999). In 1990s, the government also opened the agriculture, insurance, energy and telecommunications to FDI. These reforms uplifted the level of FDI to some extend but rapid growth cannot be attained due to political instability and inconsistency of policies. Moreover, the earthquake of 2005 and most importantly flood 2010 further reduces the charm of investment in Pakistan.

In recent periods, the need and importance of addressing some priority determinant along with classical determinants has been recognized. Among huge literature on FDI, few researchers have well acknowledged the significant contribution of infrastructure along with other determinants to attract FDI inflows. Some of them are Kok and Ersoy (2009), Sekkat and Veganzones-Varoudakis (2004), Asiedu (2002), Morrisset (2000) and Wheeler and Mody (1992). These studies argued that Multinational Corporations (MNCs) seek such markets where they can achieve cost reduction and maximization of benefits and such objective becomes easy to achieve where public goods are in better condition and supportive to investors.

Infrastructure consists on communications, roadways, transportation, highways and ports among others. In recent studies, Khadaroo and Seetanah (2010) addressed mainly on transport infrastructure along with some other variables of FDI and evidenced the positive significant contribution of infrastructure in captivating FDI. Though, the studies of Akhtar (2000) and Aqeel and Nishat (2004) contributes towards the literature on FDI for Pakistan, but these studies ignored the important determinant of FDI i.e. infrastructure (Root, 1979; Wheeler \& Mody, 1992; Kumar, 2001; Asiedu, 2002, Sekkat and Veganzones-Varoudakis, 2004; Kok \& Ersoy, 2009 and Khadaroo \& Seetanah, 2010).

The present study contributes to the existing literature by empirically examining the behavior of FDI mainly to infrastructure along with market size and exchange rate effects in Pakistan. This work also serves the objective by providing the guidelines to Government of Pakistan, UNO and International Donor Agencies for rehabilitation activities after flood 2010 with respect to FDI linkage to infrastructure.

The rest of the paper is structured that, section 2 addresses the theoretical literature review, section 3 presents data and methodology, section 4 includes empirical findings and last section, section 5 describes conclusions.

\section{Theoretical Literature Review}

\subsection{Infrastructure and FDI}

The study focuses on the specific theoretical aspects of infrastructure as a significant determinant of inward FDI. The two reasons to locate the FDI in a foreign country are discussed by Shatz and Venables (2000). The first is 'horizontal' or 'base expansion' which extends the economies of transportation costs, tariffs and access to a new market. The aim of this type on FDI is to enhance competitive position of the firm around the globe. The second reason is economies of production cost as lower labour, capital and other inputs cost to maximize the profits. Such FDI is termed as 'vertical' or minimizing production cost.

Infrastructure availability promotes both types of FDI, with comparatively more impact on vertical FDI as it reduces operational costs. Khadaroo and Seetanah (2008) claim thae gains rendered by infrastructure growth are associated with greater accessibility and reduction in transportation costs. Furthermore, public goods reduce the cost of doing business for foreign enterprises which leads towards maximization of profit. Recent empirical studies also propose that public goods have vital impact on cost structure and productivity of private firms (Quere et al., 2007; Morrison and Schwartz, 1996). Erenberg (1993) assumes that if such kinds of infrastructure were not extend to local and multinational enterprises publicly, then these enterprise would be operating with less efficiency as they would have to build their own infrastructure which is results in duplication and wastage of resources and so public inputs reduces their transportation cost. Nadiri and Mamuneas (1994) reported a cost elasticity forecasts with reference to infrastructure capital range from -0.1 to -0.21 depending on the business sector. Whereas, Bae (2008) recognizes that investment in public inputs does not pose statistically substantial direct influence on production performance in private business firms. Haughwout (2001) opposes as that availability of public goods lower the cost of private firms even if there is no direct role of infrastructure in the production performance and cost structure of private firms.

Poor infrastructure causes increase in transaction cost and limits access to both local and global markets which ultimately discourages FDI in developing countries. A greater efficiency can be achieved in extending infrastructure facilities by considering commercial principle and shifting liability for provisioning of infrastructure facilities though management contracts or leases such as build-operate-transfer (BOT), builddownoperate $(\mathrm{BOO})$ and full privatization. As a matter of fact, privatization has come up with a useful source of attracting inward FDI (Mlambo, 2006). 
Although, quality of infrastructure has impact on FDI, it also facilitates export performance which ultimately a motivational factor for inward FDI for a country as well as trading blocks. Iwanow and Kirkpatrick (2006) argue the significant contribution of quality infrastructure improvement in export performance. Furthermore the study indicates quantitative results that an improvement of $10 \%$ in infrastructure will yield $8 \%$ improvement in export performance in a developing country. Moreover, Suh and Khan (2003) explore the impact of infrastructure in the form of increased exporting level of major trade blocks CEFTA and ASEAN/AFTA.

In emerging economies, the role of infrastructure is two fold, promotion of FDI and greater return on investment to business owners. Fung et al. (2005) classify Infrastructure as hard in the shape of roadways, communications installations and highways and soft infrastructure is termed with transparent institutions and intensive reforms. Soft infrastructure is far important as to hard infrastructure to FDI. Moreover, the study describes that soft infrastructure provides twice returns, economic reforms and particularly a more market friendly soft infrastructure invites higher inward FDI in emerging economies.

Infrastructure can have different impact on developing and developed nations. In developing economies, infrastructure has a significant attractiveness for FDI inflows (Khadaroo and Seetanah, 2010; Asiedu, 2006). Sekkat and Varoudakis (2007) assess that Infrastructure has a significant attractiveness of FDI even than that of openness and investment climate in developing countries. Addison et al. (2006) acknowledge such promotional impact only for developed nations but, on the other hand, such situation not exists for developing countries. Whereas, Bae (2008) states that in developed countries, infrastructure is not a motivator but an indicator to attract FDI in large emerging economies.

With the help of above stated concise theoretical review, it is clear and convincing that infrastructure is of vital nature in developing economies with reference to inward FDI. Furthermore, literature also reasserts the non-negligible impact of infrastructure on return to owners, cost of doing business and export performance. As this study is not intended to examine these latter impacts, but attempts to examine that infrastructure is a significant determinant for attracting inward FDI. Given that flow of inward FDI to Pakistan is mainly to financial services, oil \& gas and cellular sectors, and these sectors are directly dependent on efficient infrastructure.

\subsection{Empirical Literature Review}

Wheeler and Mody (1992) and Root and Ahmed (1979) explored pioneer studies and described critical role of infrastructure for inward FDI. Among recent studies confirming this feature Khadaroo and Seetanah (2010) for Mauritius and Africa for a sample using 20 economies panel data, Kok and Erosoy (2009) by panel and cross sectional data for 24 developing countries, Belak et al. (2009) for Central Eastern European Countries, Sekkat and Varoudakis (2007) for South Asia, Africa and Middle East, Iwanow and Kirkpatrick (2006) for developing countries using panel data for a sample of 78 nations, Mlambo (2006) for Southern African Development Community member states and Obwona (2001) for Uganda. Some other similar studies also acknowledge the above result include Bae (2008) for 36 emerging economies, Li and Park (2006) for China, Asiedu (2002, 2004, 2006), Makabenta (2002) for Special Economic Zones in Philipine, and. While most of the studies found significant positive impact, but Quazi (2005) claims no effect of infrastructure on inward FDI for Asian case.

While, review of the literature recommends significant role of infrastructure in inviting inward FDI, yet studies neglected developing countries individual cases particularly lower income developing country like Pakistan. Therefore, this study seeks to fill in this gap and hence adds in literature on inward FDI.

\section{Data and Methodology}

\subsection{Description of variables and data:}

The four variables - foreign direct investment (FDI), market size (MS), infrastructure (IS) and exchange rate (EXR) - are used in this study and they are explained below with their theoretical and empirical aspects. The data has been collected for all the explanatory and dependent variable from World Development Indicators Mark 2010 online from the official website of World Bank with annual frequency for the period of 1975-2008.

\subsubsection{Infrastructure}

The cardinal variable to this study is infrastructure. As public inputs reduce the cost of doing business and remain a dominating factor for attracting FDI inflows. Khadaroo and Seetanah (2010), Kok and Ersoy (2009), Asiedu (2002, 2006), Kumar (2001), Kinoshta (1998), Wheeler and Moody (1992) and Root and Ahmad (1979) found positive impact whereas, Quazi (2005) claims insignificant effect of infrastructure on FDI. The proxy "telephone mainlines" (IS) is included in the model to measure infrastructure. Among many studies, Sekkat and 
Veganzones (2004) and Asiedu (2006) are two studies who used telephone lines as proxy for infrastructure. We expect positive sign of coefficient for infrastructure.

\subsubsection{Exchange rate}

Countries having weak currencies pull in FDI from the countries which have strong currencies as within the host economy, this investment will enjoy a better purchasing power. Whereas, economies that have stable and strong currencies deter FDI inflow as investing in strong currencies are much expensive (Zheng, 2009). Blonigen and Feenstra (1996), Blonigen (1995) and Froot \& Stein (1991) observed negative relationship between exchange rate and inward FDI whereas some studies depict insignificant impact of exchange rate on inward FDI (Kyereboah et al., 2008; and Blonigen, 1997). Official exchange rate of local currency units per US\$ (EXR) has been used to denote exchange rate in the model with the expectation of negative sign of coefficient with respect to FDI.

\subsubsection{Market Size}

Market size is considered important determinant for FDI location. Generally MNC's make this type of horizontal FDI to gain the economies of scales, transportation cost, transaction costs, tariff etc. This vital variable has positive impact in directing inward FDI to host country (Zheng, 2009; Zhang, 2008; Asiedu, 2006 and Wheeler \& Mody, 1992) but Li and Park (2006) examines insignificant effect. GDP current US\$ is incorporated in the model as proxy for market size (MS) with the expectation of positive coefficient sign for FDI inflows.

Foreign direct investment, net inflows, current US\$ (FDI) is used to measure the inward FDI

\subsection{Econometric Model}

The objective of this study is to investigate the impact of infrastructure, after considering other important determinants, on FDI inflows. The hypothesis, that a low income country like Pakistan, with better infrastructure, are more attractive to foreign firms, is analyzed by incorporating an appropriate proxy in reduced form specifications for the demand of inward FDI.

We specify the following equation to investigate the effects of infrastructure on FDI along with market size and exchange rate.

$$
\ln \left(\mathrm{FDI}_{\mathrm{t}}\right)=\boldsymbol{\beta}_{0}+\boldsymbol{\beta}_{1} \ln \left(\mathrm{MS}_{\mathrm{t}}\right)+\boldsymbol{\beta}_{2} \ln \left(\mathrm{IS}_{\mathrm{t}}\right)+\boldsymbol{\beta}_{3} \ln \left(\mathrm{EXR}_{\mathrm{t}}\right)+\mathrm{Ut}
$$

Where $\mathrm{FDI}_{\mathrm{t}}, \mathrm{MS}_{\mathrm{t}}, \mathrm{IS}_{\mathrm{t}}$ and EXR ${ }_{\mathrm{t}}$ represent foreign direct investment, market size, infrastructure and exchange rate. Whereas, ln represent natural logarithmic form of series. Parameters $\beta_{1}, \beta_{2}$ and $\beta_{3}$ are the long run elasticities of foreign direct investment net inflows with respect to MS, IS and EXR respectively. Engle and Granger (1987) test and Johasen-Juselius (1990) test are the most widely used methods to identify cointegration (long run equilibrium relationship) among variables. These methods require that all variables to be stationary at first difference i.e. I(1). In case of small sample size, poor performance of these methods has been observed (Chaudhry and Choudhary, 2006). Autoregressive distributed lag (ARDL) approach to conintegration avoids such limitation. Pesaran, Shin and Smith (1996) developed this approach, whereas, Pesaran et. al. (2001) popularized it. Due to various econometric merits, this approach gained acceptance as contrary to other approaches, it does not necessitate that all variables to be stationary at same order i.e. I(1). This approach is indifferently good if all variables in a model are $\mathrm{I}(0)$ or even fractionally conintegrated (Pesaran \& Pesaran, 1997). Considering the above benefits of ARDL approach to conintegration, we specify the following model:

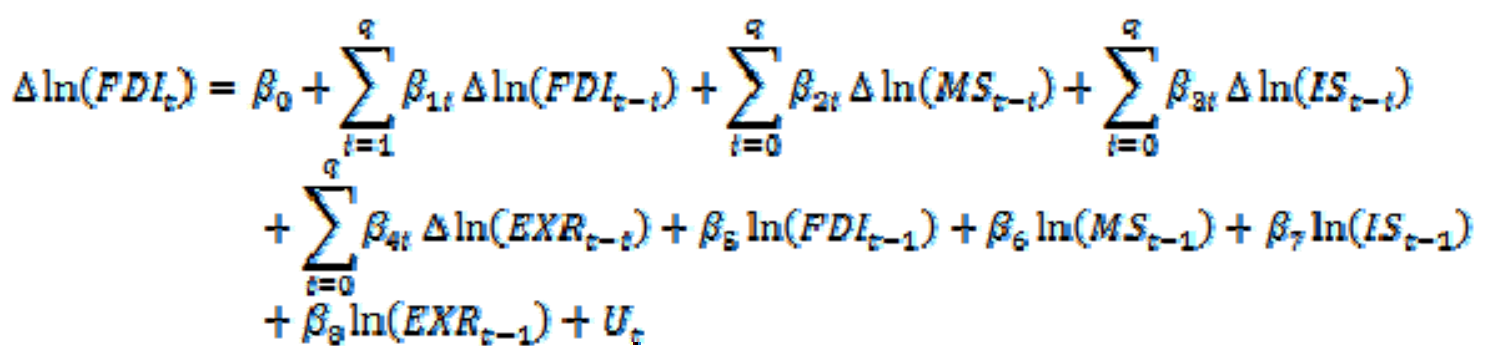

Where, $\Delta$ is the first difference operator, $\mathrm{q}$ is the optimal lag length, $\beta_{1,} \beta_{2}, \beta_{3}$ and $\beta_{4}$ represents the short run dynamics and $\beta_{5}, \beta_{6}, \beta_{7}$ and $\beta_{8}$ represents long run elasticities. Before applying ARDL approach, we test the level of integration of all variables because if any variable is I(2) or above, ARDL approach is not applicable. For this we use Phillips-Perron (PP) test statistic. 
In order to find long run relationship as given in equation 3.1, we conduct bound test of equation 3.2 using F-statistic with upper and lower bounds. The null hypothesis assumes no conintegration among variables. In case of value of F-statistic is greater than the upper bound we reject null hypothesis and if it is less than lower bound then we accept null hypothesis and if the value of F-statistic falls between lower and upper bound, the test is inconclusive. After testing cointegration we use Akaike Information Criterion (AIC) and Schwarz Bayesian Information Criterion (SBC) to select the optimal lag length of variables. An error correction version of equation 3.2 is given as below:

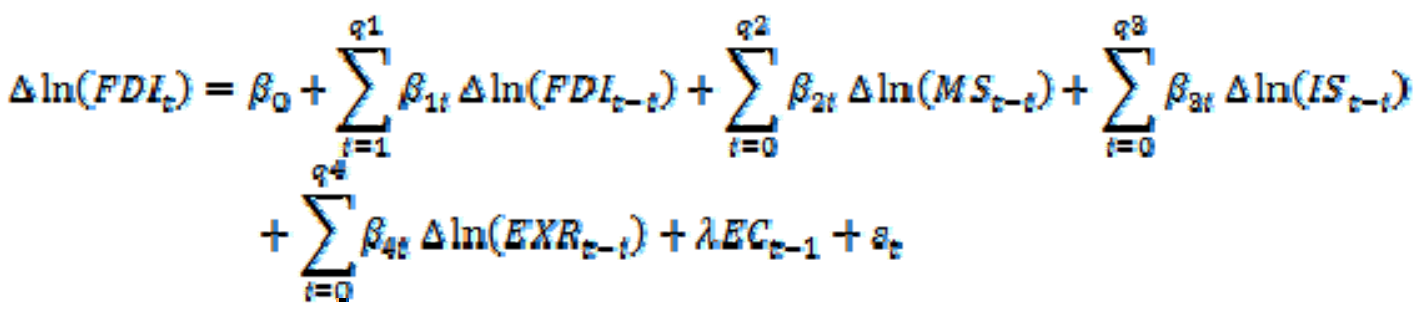

Where, $\mathrm{q} 1, \mathrm{q} 2, \mathrm{q} 3$ and $\mathrm{q} 4$ represent optimal lag length, $\mathrm{a}$ is the speed of adjustment parameter and EC represent error correction term derived from long run relationship as given in equation 3.2.

\section{Empirical Findings}

Unit roots of variables are tested before applying the ARDL approach to cointegration. Results of unit roots under Phillips-Perron test are summarized in Table 1 . As per results, $\ln (\mathrm{IS})$ is stationary at five percent significance level at first difference, whereas all other variables $\ln (\mathrm{FDI}), \ln (\mathrm{EXR})$ and $\ln (\mathrm{MS})$ are stationary at first difference form at one percent level of significance. ARDL approach to cointegration can be applied in this case.

----- Table 1 here-----

Optimal lag-length has been selected in the model as it is sensitive to results of long run relationship. Lower and upper bond values at $99 \%$ significance level are 4.29 and 5.61 respectively at lag equal to three (Bahmani-Oskooee and Bohal, 2001). Computed value of F-statistics (5.71), in Table 2, is greater than the upper bond value which depicts evidence against null hypothesis of no level effect and hence long run relationship among variables is concluded.

----- Table 2 here-----

Table 3 shows the results of long run relationship of the selected ARDL model $(2,0,0,0)$ using Akaike Information Criterion (AIC) and Schwarz Bayesian Information Criterion (SBC) to select optimal lag length in the model and we got the same output under these two criterion.

----- Table 3 here-----

Table 3 shows the results that IS is significant factor at five percent of foreign direct investment in Pakistan. The coefficient of $\operatorname{lnIS}$ represents that by one percent increase in IS, FDI increases by $1.31 \%$. Present studies support the findings of Khadaroo and Seetanah (2010) Asiedu (2002) and Root and Ahmed (1979). The EXR is significant at five percent and its coefficients (-1.54) depicts that one percent increase in EXR decreases FDI by $1.54 \%$. MS is significant at one percent and its coefficient reflects that one percent increase in MS raises FDI by $2.27 \%$

----- Table 4 here------

The results of error correction representation of the selected ARDL model are summarized in table 4 . Coefficients of variables with $\Delta$ sign represent short run elasticity. The results shows that IS in short run significant relationship with coefficient of 1.03 at five percent which means one percent increase in IS results $1.03 \%$ increase in FDI in short run, whereas EXR and MS are significant at five and one percent level -1.54 and 1.80 respectively. The coefficient of error correction term (ECM (-1)-0.79) is significant at one percent. We can observe that IS is significantly positive impact on FDI inflows in short and as well as in long run. Highly significance of ECM (-1) evidenced long run relationship among the variables. The speed of adjustment from previous year's equilibrium in foreign direct investment to current period's equilibrium is $79 \%$.

The value of $\mathrm{R}^{2}=0.50$ shows that $50 \%$ variations in dependent variable are explained by independent variables incorporated in the model. Value of F-statistics is $\mathrm{F}(5,25)=5.06(0.002)$ and significant at less than one percent 
level which indicates that mode is a good fit. Moreover, Durbin Watson statistic are D.W. Statistic $=2.09$ which depicts that there is no auto correlation problem in the model

We tested the stability of the selected ARDL based error correction model by using cumulative sum of recursive residuals (CUSUM) and cumulative sum of squares residuals (CUSUMSQ), stability technique given by Brown et al. (1975). Figure 1 and 2 show the CUSUM and CUSUMSQ respectively. Since both plots remain within 5\% critical bonds at $5 \%$ level of significance, we conclude that the model is structurally stable.

----- Figure 1 \& 2 here-----

\section{Conclusions}

The purpose of this study was to investigate empirically the effects of infrastructure availability on FDI inflows in a developing nation like Pakistan. Some other important variables, market size and exchange rate, have also been incorporated along with infrastructure which is cardinal variable in this study. The motivation behind this work was that it is felt to give some guidelines for rehabilitation activities after flood 2010 in Pakistan with special consideration to infrastructure and FDI. Moreover, while conducting this work, we could not find any exclusive study which addressed infrastructure impact on FDI in case of Pakistan. By using time series data from 1975 to 2008 and by applying autoregressive distributive lag (ARDL) approach to cointegration, we find out the significant positive impact in short and long run of infrastructure on FDI inflows in Pakistan. In short run, one percent increase in infrastructure results in uplifting FDI by $1.03 \%$ and in long run, one percent rise in infrastructure enhances FDI inflows by $1.31 \%$. while discussing other variables, market size also have positive significant relationship in short and long run whereas, exchange rate has negative significant impact of infrastructure in short and long run. These results are according to our expectations. While discussing research limitations/implications, this study is conducted on a low income country Pakistan, which has its own local dynamics, so the result of this study cannot be generalized to all developing countries. Further more, in future, it is recommended that researchers authenticate the model in various contexts and to modify the model as per requirements. The findings of this study present following policy implications.

- Firstly, the international donor agencies like UNO, ADB and IMF and Pakistan's friend countries should primarily focus on infrastructure reconstruction as it will result in twofold benefit, first is rehabilitation and second is in maintaining and uplifting FDI inflows.

- Secondly, the government policy makers should also pay key consideration to infrastructure along with other factors while making policies in respect of FDI.

\section{References}

Addison, T., Khansnobis, G.B., \& Mayrotas, G. (2006). Introduction and Overview. World Economy, 29(1), 1-8.

Akhar, H. M. (2000). The determinants of FDI in Pakistan: An Econometrics Analysis: The Lahore Journal of Economics, 5:1

Aqeel, A., \& Nishat M. (2004). The determinants of foreign direct investment in Pakistan. The Pakistan Development Review, 43(4) II, 651-664.

Asiedu, E. (2002). On the determinants of foreign direct investment to developing countries: is Africa different? World Development, 30(1), 107-118.

Asiedu, E. (2004). Policy Reform and Foreign Direct Investment in Africa: Absolute Progress but Relative Decline. Development Policy Review, 22(1), 41-48.

Asiedu, E. (2006). Foreign direct investment in Africa: the role of government policy, institutions and political instability. World Economy, 29(1), 63-77.

Bae, M. T. (2008). Foreign Direct Investment Inflows and ICT Configurations. Pacific Focus, 17(2), 217-226.

Blonigen, B. A. (1995). Explaining Japanese Foreign Direct Investment in the United States. Unpub-lished Ph. D. Dissertation, University of California, Davis.

Blonigen, B. A. (1997). Firm-specific Assets and the Link Between Exchange Rates and Foreign Direct Investment. American Economic Review, 87, 447- 465.

Blonigen, B. A., \& Feenstra, R. C. (1996). Effects of U. S. Trade Protection and Promotion Policies, National Bureau of Economic Research (Cambridge, M. A.) Working Paper No. 5285.

Brown, R. L., Durbin, J., \& Evans, J. (1975). Techniques for Testing the Constancy of Regression Relations over Time. Journal of the Royal Statistical Society, 37, 149-163 
Chaudhry, M. A., \& Choudhary, M. A. S. (2006). Why the State Bank of Pakistan should not adopt inflation targeting. SBP-Research Bulletin 2(1).

Engle, R., \& Granger, C. (1987). Co-Integration and Error Correction Representation, Test and Telling. Econometrica, 55(2), 251-276.

Erenberg, S. J. (1993). The real effects of public investment on private investment. Applied Economics, 23, 831-837.

Froot, K. A., \& Stein, J. C. (1991). Exchange Rates and Foreign Direct Investment: An Imperfect Capital Markets Approach. Quarterly Journal of Economics, 106, 1191-1217.

Fung, C. K., Herrero, G.A., Ilzakas, H., \& Siu, A. (2005). Hard or Soft? Institutional Reforms and Infrastructure Spending as Determinants of Foreign Direct Investment in China. Japanese Economic Review, 56(4), 408-416.

Haughwout, A. F. (2001). Infrastructure and social welfare in Metropolitan America. Economic Policy Review, $7(3), 43-54$.

Iwanow, T., \& Kirkpatrick, C. (2006). Trade facilitation, regulatory quality and export performance. Journal of International Development, 19(6), 735-753.

Johansen, S., \& Juselius, K. (1990). Maximum Likelihood Estimation and Inference on Co-Integration with Application for the Demand for Money. Oxford Bulletin of Economics and Statistics, 52, 169-210.

Khadaroo, A. J., \& Seetanah, B. (2010). Transport infrastructure and foreign direct investment. Journal of International Development, 22, 103-123.

Khadaroo, A. J., \& Seetanah, B. (2008). Transport and economic performance: the case of Mauritius. Journal of Transport Economics and Policy, 42(2), 1-13.

Khan, H. A., \& Kim, Y. (1999). EDRC (Report Series No. 66)

Kinoshita, Y. (1998). Micro-determinants of Japanese Foreign Direct Investment in Asia. Eastern Economic Association and Japan Economic Seminar at Columbia University.

Kok, R., \& Ersoy, A. B. (2009). Analyses of FDI determinants in developing countries. International Journal of Social Economics, 36(1/2), $105-123$.

Kumar, N. (2001). Infrastructure Availability, Foreign Direct Investment Inflows and Their Export-orientation: A Cross-Country Exploration. Research and Information System for Developing Countries, New Delhi, November 2001.

Kyereboah-Coleman, A., \& Agyire-Tettey, F., K. (2008). Effect of exchange-rate volatility on foreign direct investment in Sub-Saharan Africa. The case of Ghana, Journal of Risk Finance, 9(1), 52 - 70.

Li, S., \& Park, S. H. (2006). Determinants of Locations of Foreign Direct Investment in China. Management and Organization Review, 2, 95-119.

Makabenta, P. M. (2002). FDI Location and Special Economic Zones in the Philippines. Review of Urban and Regional Development Studies, 14(1), 59-77.

Mlambo, K. (2006). Reviving Foreign Direct Investments in Southern Africa: Constraints and Policies. African Development Review, 17(3), 552-579.

Morrison, C., \& Schwartz, A. (1996). State infrastructure and productive performance. American Economic Review, 86(5).

Morrisset, P. (2000). Foreign Direct Investment to Africa: Policies also Matter. Transnational Corporation, 9(2), 107-125.

Obwona, M. B. (2001). Determinants of FDI and their Impact on Economic Growth in Uganda. African Development Review, 13, 46-81.

Pesaran, H., \& Pesaran, B. (1997). Microfit 4.0 interactive econometric analysis. Oxford: Oxford University Press.

Pesaran, H. M., Shin, Y., \& Smith, R. J. (2001). Bounds Testing Approaches to the Analysis of Long-Run Relationships. Journal of Applied Econometrics, 16, 289-326.

Pesaran, M. H., Shin, Y., \& Smith, R. J. (1996). Testing for the 'Existence of a long-run relationship', Faculty of Economics, University of Cambridge, Cambridge Working Papers in Economics 9622. 
Quazi, R. (2005). Economic Freedom and Foreign Direct Investment in East Asia, College of Business, Prairie View A\&M University, Prairie View, Texas 77446. USA International Academy of Business and Public Administration Disciplines (IABPAD) Meetings.

Quere, B. A., Gobalraia, N., \& Trannoy, A. (2007). Tax and public input competition. Economic Policy, 22(50), 385-430.

Root, F.R., \& Ahmed, A. (1979). Empirical determinants of manufacturing direct foreign investment in developing countries. Economic Development and Cultural Change, 27, 751-767.

Sekkat, K., \& Varoudakis, A.M. (2007). Openness, Investment Climate and FDI in Developing Countries. Review of Development Economics, 11(4), 607-620.

Sekkat, K., \& Varoudakis, M. (2004). Trade and Foreign Exchange Liberalization, Investment Climate and FDI in the MENA Countries. Working Papers DULBEA, University of Oxford: Oxford.

Shatz, H., \& Venables, A.J. (2000). The Geography of International Investment. World Bank Policy Research Working Paper 2338.

Suh, T., \& Khan J. O. (2003). The effect of FDI inflows and ICT infrastructure on exporting in ASEAN/AFTA countries: A comparison with other regional blocs in emerging markets. International Marketing Review, 20(5), $554-571$.

Wheeler, D., \& Mody A. (1992). International investment location decisions: the case of U.S. firms. Journal of International Economics, 33, 57-76.

Zhang, H. K. (2008). What attracts Foreign Multinational Corporations to China? Contemporary Economic Policy, 19(3), 336-346.

Zheng, P. (2009). A Comparison of FDI determinants in China and India. Thunderbird International Business Review, 51(3), 263-279.

Table 1. Unit Root Test

\begin{tabular}{|l|c|c|c|}
\hline Variables & $\begin{array}{c}\text { Phillips-Perron } \\
\text { Test Statistic } \\
\text { (at level) }\end{array}$ & $\begin{array}{c}\text { Phillips-Perron Test } \\
\text { Statistic } \\
\text { (at first difference) }\end{array}$ & $\begin{array}{c}\text { Stationary } \\
\text { Status }\end{array}$ \\
\hline $\ln \mathrm{FDI}$ & -0.12 & $-6.13^{*}$ & $\mathrm{I}(1)$ \\
\hline $\ln \mathrm{MS}$ & -0.74 & $-4.29^{*}$ & $\mathrm{I}(1)$ \\
\hline $\ln \mathrm{IS}$ & -1.04 & $-3.32^{* *}$ & $\mathrm{I}(1)$ \\
\hline $\ln \mathrm{EXR}$ & 0.01 & $-3.86^{*}$ & $\mathrm{I}(1)$ \\
\hline
\end{tabular}

Note: *and ${ }^{* *}$ show significance level at $1 \%$ and $5 \%$ respectively

Table 2. F-Statistics for Testing the Existence of Long-Run Relationship

\begin{tabular}{|c|c|}
\hline Order of Lag & F-Statistics \\
\hline 3 & 5.71 \\
\hline
\end{tabular}

Note: The lower and upper bound values (4.29 and 5.61 at 99\%) for F-Statistics are taken from Table CI(iii) case III: Unrestricted intercept and no trend given in Pesaran et al. (2001)

Table 3. Long Run Results of ARDL (2,0,0,0) Model Dependent Variable "FDI"

\begin{tabular}{|l|c|c|c|}
\hline Regressor & Coefficient & Standard Error & t-Ratio \\
\hline Constant & -48.37 & 10.05 & $-4.81^{*}$ \\
\hline $\ln (\mathrm{MS})$ & 2.27 & 0.48 & $4.74^{*}$ \\
\hline $\ln (\mathrm{IS})$ & 1.31 & 0.62 & $2.11^{* *}$ \\
\hline $\ln (\mathrm{EXR})$ & -1.95 & 0.90 & $-2.17^{*}$ \\
\hline
\end{tabular}

Note: *and ** show significance level at $1 \%$ and $5 \%$ respectively 
Table 4. Error Correction Representation of the Selected ARDL $(2,0,0,0)$ Model Dependent Variable "FDI"

\begin{tabular}{|l|c|c|c|}
\hline Regressor & Coefficient & Standard Error & t-Ratio \\
\hline$\Delta \ln (\mathrm{FDI})$ & 0.30 & 0.16 & 1.94 \\
\hline$\Delta \ln (\mathrm{MS})$ & 1.80 & 0.55 & $3.26^{*}$ \\
\hline$\Delta \ln (\mathrm{IS})$ & 1.03 & 0.47 & $2.21^{* *}$ \\
\hline$\Delta \ln (\mathrm{EXR})$ & -1.54 & 0.68 & $-2.27^{* *}$ \\
\hline $\mathrm{ECM}(-1)$ & -0.79 & 0.17 & $-4.69^{*}$ \\
\hline
\end{tabular}

Note: *and ** show significance level at $1 \%$ and $5 \%$ respectively

$\mathrm{R}^{2}=0.50, \quad$ Adj. $\mathrm{R}^{2}=0.40, \quad \mathrm{~F}(5,25)=5.06(0.002)$, D.W. Statistic $=2.09$

Plot of Cumulative Sum of Recursive Residuals

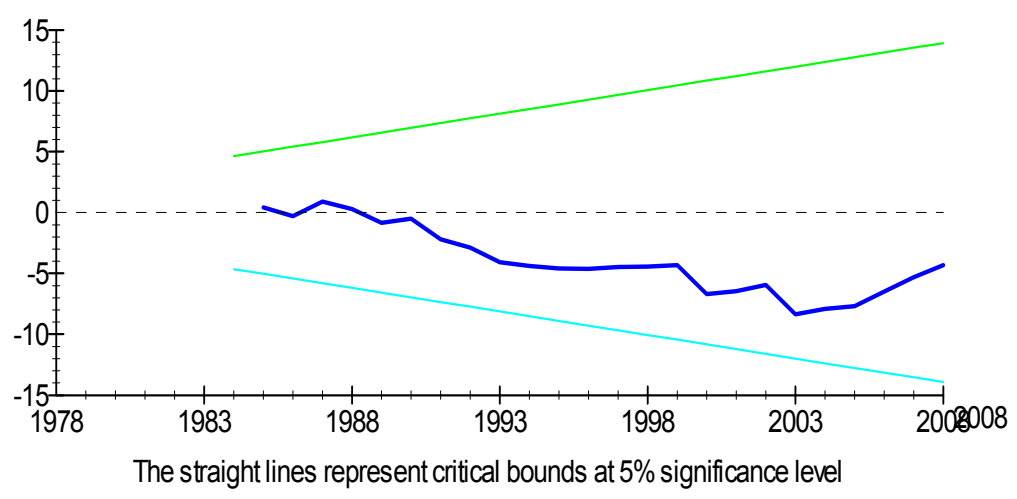

Figure 1.

Plot of Cumulative Sum of Squares of Recursive Residuals

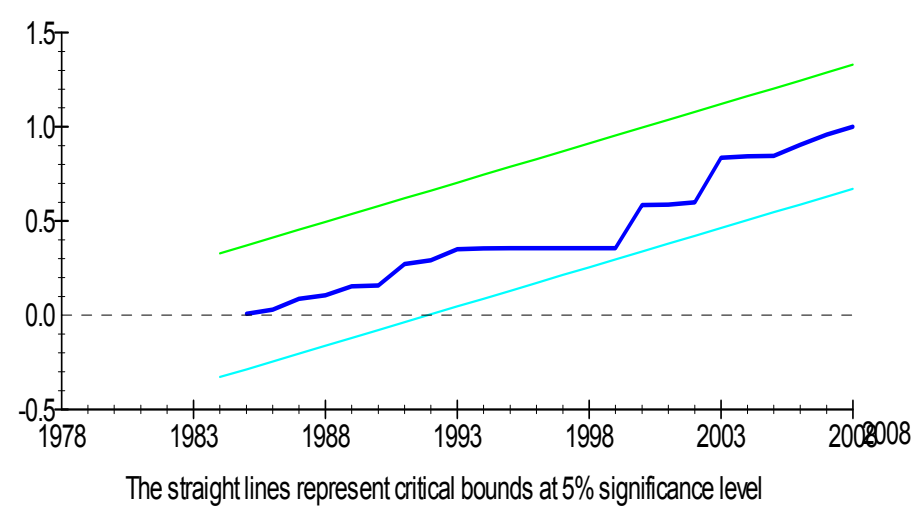

Figure 2. 